\title{
Chronotype and Sleep Quality Assessment of Patients with Polycystic Ovary Syndrome
}

\author{
Polikistik Over Sendromu Olan Hastalarda Kronotip ve Uyku Kalitesi \\ Değerlendirmesi
}

\author{
๑ Ayse Filiz Gökmen Karasu, ๑ Ciğdem Dilek Şahbaz*, ๑ Zeynep Filiz Eren Doğu**, \\ ๑ Taha Takmaz, ๑ Halime Çalı, ๑ Başak Tanoğlu \\ Bezmialem Vakıf University Hospital, Clinic of Obstetrics and Gynecology, Istanbul, Turkey \\ *Biruni University Hospital, Clinic of Psychiatry, Istanbul, Turkey

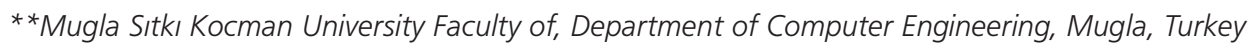

\section{Abstract}

Aim: Polycystic Ovary Syndrome (PCOS) is the most common endocrine disorder among women during the reproductive ages. The purpose of this study was to investigate the chronotype and sleep quality of PCOS patients.

Methods: Volunteering nulliparous participants who were diagnosed with PCOS and a convenience sample of healthy controls without accompanying chronic medical conditions who presented to the Bezmialem University gynecology outpatient clinic were enrolled in the study. Participants were asked to fill out the Turkish versions of Morningness Eveningness Questionnaire (MEQ) and Pittsburgh Sleep Quality index Questionnaire (PSQIQ).

Results: There were 111 participants in the PCOS group and 108 participants in the healthy control group. Both groups were similar in age $(p=0.24)$ and body mass index $(p=0.9)$. The prevalance of hirsutism ( $\mathrm{mFG} \geq 8$ ) was $33.3 \%$ among PCOS patients. Subjective sleep quality $(<0.001)$, sleep latency $(<0.001)$, habitual sleep efficiency (0.003), utilization of sleep medication (0.03) and daytime dysfunction $(<0.001)$ scores were significantly different between the groups. In the PCOS group, MEQ score was inversely correlated with the mFG score and fT levels. There was a negative correlation between MEQ-mFG ( $r=-$ 0.59, p<0.001).

Conclusion: PCOS patients were more prone to eveningness chronotype and had worse sleep quality compared to controls. Furthermore PCOS patients with hirsutism were more evening oriented and had more difficulty falling asleep compared to those without hyperandrogenism.

Keywords: PCOS, sleep, chronotype, hirsutism, PSQIQ, MEQ
Amaç: Polikistik Over Sendromu (PKOS) reprodüktif çağdaki kadınlarda en sık izlenen endokrin problemdir. Bu çalışmamızdaki amacımız PKOS hastalarının kronotipini belirlemek ve uyku kalitelerini değerlendirmektir.

Yöntemler: Daha önce doğum yapmamış PKOS hastaları ve herhangi bir kronik sağlık problemi bulunmayan Bezmialem Üniversitesi jinekoloji polikliniğine başvuran gönüllü erişkinler çalışmaya dahil edilmişlerdir. Çalışmaya dahil edilenlerden Türkçe validasyonu olan Sabahçıl Akşamcı (MEQ) ve Pittsburgh Uyku Kalitesi indeksi (PSQIQ) ölçeklerini doldurmaları istenmiştir.

Bulgular: PKOS grubunda 111, kontrol grubunda 108 gönüllü yer almıştır.Her iki grup da yaş $(p=0,24)$ ve vücut kitle indeksi (VKi) $(p=0.9)$ açısından benzerdi. PKOS hastaları arasında hirsutizm prevalansı ( $\mathrm{mFG}>8$ ) \%33,3 idi. Subjektif uyku kalitesi $(p<0,001)$, uykuya dalama süresi $(p<0,001)$, alışılmış uyku etkinliği $(p=0,003)$, uyku ilacı kullanımı $(p=0,03)$ ve gündüz işlev bozukluğu $(p<0,001)$ anlamlı olarak PCOS grubunda daha kötüydü. PKOS grubunda MEQ skoru mFG skoru ile negatif korelasyon MEQ-mFG $(r=-0,59, p<0,001)$ gösteriyordu.

Sonuç: PKOS kontrol grubu ile karşılaştırıldığında akşamcıl kronotipe daha yatkındılar. Hirsutizm mevcut olan PKOS hastaları ise hirsutizm olmayan hastalara göre daha fazla akşamcıl kronotipe sahipti ve uykuya dalma konusunda daha fazla problem yaşıyordu.

Anahtar Sözcükler: PKOS, uyku, kronotip, hirsutizm, PSQIQ, MEQ
Address for Correspondence/Yazışma Adresi: Ayse Filiz Gökmen Karasu, Bezmialem Vakıf University Hospital Clinic of Obstetrics and Gynecology, Istanbul, Turkey E-mail: afgokmen@gmail.com ORCID: orcid.org/0000-0001-7480-4691 Received/Geliş Tarihi: 04.10.2020 Accepted/Kabul Tarihi: 01.01.2021
${ }^{\circ}$ Copyright 2021 by The Medical Bulletin of istanbul Haseki Training and Research Hospital The Medical Bulletin of Haseki published by Galenos Yayinevi. ${ }^{8}$ Telif Hakkı 2021 istanbul Haseki Eğitim ve Araştırma Hastanesi Haseki Tıp Bülteni, Galenos Yayınevi tarafından yayınlanmıştır. 


\section{Introduction}

Polycystic Ovary Syndrome (PCOS) is the most common endocrine disorder among women during the reproductive ages. Epidemiological investigations have shown that 6-8\% of women are affected by PCOS (1). The disorder is defined by polycystic ovaries on ultrasound examination, clinical and/or biochemical hyperandrogenemia, oligomenorrhea and/or amenorrhea (2). The diagnosis of PCOS has longlasting associations including obesity, metabolic syndrome, diabetes mellitus and increased risk of endometrial carcinoma $(3,4)$.

The timing of physiological functions, such as core body temperature, hormone secretion, and wake onset, differs between individuals. Based on these individual differences, humans can be classified as the earlier-timed morning types, the intermediate types or the later-timed evening types (5-7). Several studies have demonstrated that circadian preference towards eveningness is associated with an unhealthy lifestyle, including an unhealthy diet, various health problems, and psychopathology (8). We also have recently demonstrated that in pregnancy evening-types were significantly greater compared to morning-types in high risk pregnancies such as preterm birth and preeclampsia (9).

Sleep quality is associated with general well being (10) and metabolic syndrome $(11,12)$. Sleep deprivation as well as prolonged sleep, or long-term circadian misalignment between the sleep-wake cycle and circadian rhythms, alter the hormonal regulation and metabolism $(13,14)$. Sleep disturbances in PCOS patients have been examined before. Most of the literature until now focuses on increased prevalance of sleep apnea among PCOS patients (15-17). The purpose of our study was to investigate the chronotype and sleep quality of PCOS patients.

\section{Methods}

This study was conducted at Bezmialem University Hospital. Institutional review board approval was attained (Number: 11/213/2019).

\section{Partipant Selection}

Volunteering nulliparous participants who were diagnosed with PCOS and a convenience sample of healthy controls without accompanying chronic medical conditions who presented to the Bezmialem University gynecology outpatient clinic were enrolled in the study. Parous women and night shift workers were excluded. PCOS diagnosis was made according to the Rotterdam consensus as two of the following three criteria: oligoovulation/anovulation, biochemical or clinical hyperandrogenism and the presence of polycystic ovaries on ultrasound. Polycystic ovarian morphology was defined as one or more ovaries with a volume $>10 \mathrm{~cm}^{3}$ (18). Oligomenorrhea was defined as less than 10 menstrual cycles annually. Amenorrhoea was defined as the lack of menstruation for 6 months or longer (19). Clinical hyperandrogenism was defined as the presence of hirsutism (mFG score $>8$ ) (20). None of the participants were taking any medications including oral contraceptives.

\section{Assessing Sleep Quality and Chronotype}

All participants were asked to fill out the Turkish versions of Morningness Eveningness Questionnaire (21) and Pittsburgh Sleep Quality Index Questionnaire (PSQIQ) (22). The Morningness Eveningness Questionnaire (MEQ) was developed by Horne and Ostberg (23). MEQ is a 19-item assay tool analysing habitual wakefulness, sleep times, favored times of mental/physical performance and subjective vigilance after waking up and before going to sleep. Total scoring ranges between 16-86. High scores indicate morningness chronotype and low scores indicate eveningness chronotype.

The PSQIQ is composed of 19 scoring items which assess sleep disordes in 7 categories: (P1)-subjective sleep quality, (P2)-sleep latency, (P3)-sleep duration, (P4)-habitual sleep efficiency, (P5)-sleep disturbance, (P6)-utilization of sleeping medication and (P7)-daytime dysfunction. Each of the 19 items are designated scores ranging between 0-3. Zero score indicates no difficulty; 3 indicates severe difficulty. A total score above 5 indicates poor sleep quality.

\section{Biochemistry Assays}

For the PCOS patients only; blood samples were obtained between 08.00-08.30 a.m after overnight fasting in the early follicular phase of the spontaneous menstrual cycle (days 2-5) or following progesterone-induced withdrawal bleeding. Follicle Stimulating Hormone (FSH), Luteinizing Hormone (LH), Thyroid Stimulating Hormone (TSH), Estradiol (E2) prolactin, free testesterone (fT), Dehydroepiandrosterone (DHEAS), total cholesterol, low density lipoprotein (LDL), triglyceride (TG), insulin, glucose and Homeostatic Model Assessment for Insulin Resistance index (HOMA-IR) was assessed. The formula used for HOMA-IR was: fasting blood glucose ( $\mathrm{mmoL} / \mathrm{L}) \times$ fasting serum insulin $(\mathrm{mU} / \mathrm{mL}) / 22.5$.

Plasma FSH, LH, prolactin and DHEAS and insulin concentrations were measured by a direct chemiluminescence immunoassay. E2, fT concentrations were determined by a competitive chemiluminescent immunoassay (ADVIA Centaur, Siemens Healthcare Diagnostics). LDL and TG were determined by calorimetric methods. Serum glucose concentrations were analysed by an enzymatic UV method (Roche/Hitachi cobas c system).

\section{Statistical Analysis}

The statistical analysis was performed using $R$ statistical software (version 3.3.3). Data were expressed 
as mean \pm standard deviation or number and percentage, $\mathrm{A}$ $p$ value of $<.05$ was considered statistically significant. The distribution of data was assessed with histogram analysis and the Kolmogorov-Smirnov test. Comparisons for sleep disturbance between women with and without PCOS in the analysis sample were made using chi-square tests of association, independent samples t-tests and MannWhitney $U$ test, for categorical, normally distributed and skewed continuous variables, respectively. Comparisons were performed for PCOS patients according to their hirsutism status determined by their mFG score. For the group of women with PCOS logistic regression was used to quantify associations between sleep disturbance and other factors that are potentially influential.

\section{Results}

1-The demographic characteristics of PCOS and healthy control groups

There were 111 participants in the PCOS group and 108 participants in the healthy control $(\mathrm{HC})$ group. The patients in the PCOS group were aged 25.12 \pm 5.81 . The mean BMI for PCOS patients was 26.47 \pm 5 .10. The control group was aged $26.37 \pm 9.4$. The mean BMI of the control group was $26.46 \pm 4.95$. Both groups were similar with regards to age $(p=0.24)$ and $B M I(p=1)$. The prevalance of hirsutism ( $m-F G \geq 8$ ) was $37 / 111$ among PCOS patients (33.3\%).

\section{2- PSQIQ scoring and chronotype analysis of groups}

For the analysis sample, comparisons between PCOS and HC group are presented in Table 1. The mean of PSQIQ

\begin{tabular}{|c|c|c|c|}
\hline \multicolumn{4}{|c|}{$\begin{array}{l}\text { Table 1. Characteristics of Polycystic Ovary Syndrome and } \\
\text { healthy control groups }\end{array}$} \\
\hline Characteristics & $\begin{array}{l}\text { Pcos group } \\
\mathrm{n}=111\end{array}$ & $\begin{array}{l}\text { HC group } \\
n=108\end{array}$ & $p$-value \\
\hline Age & $25.13 \pm 5.82$ & $26.4 \pm 9.4$ & 0.2 \\
\hline BMI & $26.47 \pm 5.10$ & $26.5 \pm 5.0$ & 0.9 \\
\hline Total PSQI & $7.0 \pm 4.5$ & $4 \pm 3$ & $<0.001$ \\
\hline P1. Subjective Sleep Quality & $1.69 \pm 0.92$ & $1.36 \pm 0.71$ & $<0.001$ \\
\hline P2. Sleep Latency & $3.34 \pm 0.87$ & $1.45 \pm 0.91$ & $<0.001$ \\
\hline P3. Sleep Duration & $1.72 \pm 1.3$ & $1.66 \pm 0.8$ & 0.3 \\
\hline $\begin{array}{l}\text { P4. Habitual Sleep } \\
\text { Efficiency }\end{array}$ & $1.52 \pm 0.8$ & $1.32 \pm 0.8$ & 0.03 \\
\hline P5. Sleep Disturbance & $1.18 \pm 1.12$ & $1.02 \pm 1.17$ & 0.09 \\
\hline $\begin{array}{l}\text { P6. Utilization of Sleeping } \\
\text { Medication }\end{array}$ & $1.2 \pm 0.8$ & $0.9 \pm 0.1$ & 0.03 \\
\hline P7. Daytime Dysfunction & $1.72 \pm 0.81$ & $1.29 \pm 0.83$ & $<0.001$ \\
\hline MEQ & $48.26 \pm 7.25$ & $55.2 \pm 7.7$ & $<0.001$ \\
\hline \multicolumn{4}{|c|}{$\begin{array}{l}\text { BMI: Body Mass Index, PSQI: Pittsburgh Sleep Quality index } \\
\text { Questionnaire, MEQ: Morningness Eveningness Questionnaire, PCOS: } \\
\text { Polycystic Ovary Syndrome, HC: Healthy Control }\end{array}$} \\
\hline
\end{tabular}

scores for the PCOS and HC groups were calculated as: $7 \pm 4.5$ and $4 \pm 3$, respectively. There was a significant total PSQIQ score difference between the groups $(p<0.001)$. In terms of the subcategories of sleep disorder; P1 $(<0.001)$, P2 (<0.001), P4 (0.003), P6 (0.03) and P7 (<0.001) scores were higher for the PCOS group. P3 $(p=0.3)$ and P5 $(p=0.09)$ scores were not different. Statistically significant differences between the groups were also observed in relation to MEQ $(p<0.001)$.

\section{3- Correlation anaysis}

In the PCOS group, we conducted a correlation analysis, for PSQI and dependent variables. In the correlation test, the PSQI score was positively associated with age ( $r=0.199, p=0.042)$; and MEQ ( $r=0.187$, $\mathrm{p}=0.049$ ). For the other factors (BMI, mFG, PSQI, glucose, insulin, HOMA.IR, cholesterol, LDL, TG, fT) no linear effect on PSQI score was observed. Moreover, MEQ score was inversely correlated with the $\mathrm{MFG}$ score and fT levels. The significant correlations are as follows: negative correlations between MEQ-fT $(r=-0.5, p<0.001)$ and MEQ-mFG ( $r=-$ $0.59, p<0.001)$, and positive correlation between $\mathrm{mFG}-\mathrm{fT}$ $(r=0.52, p<0.001)$ (Figure 1).

In the PCOS group, we conducted a correlation analysis, for PSQI and dependent variables. In the correlation test, the PSQI score was positively associated with age $(r=0.199, p=0.042)$; and MEQ $(r=0.187, p=0.049)$. For the

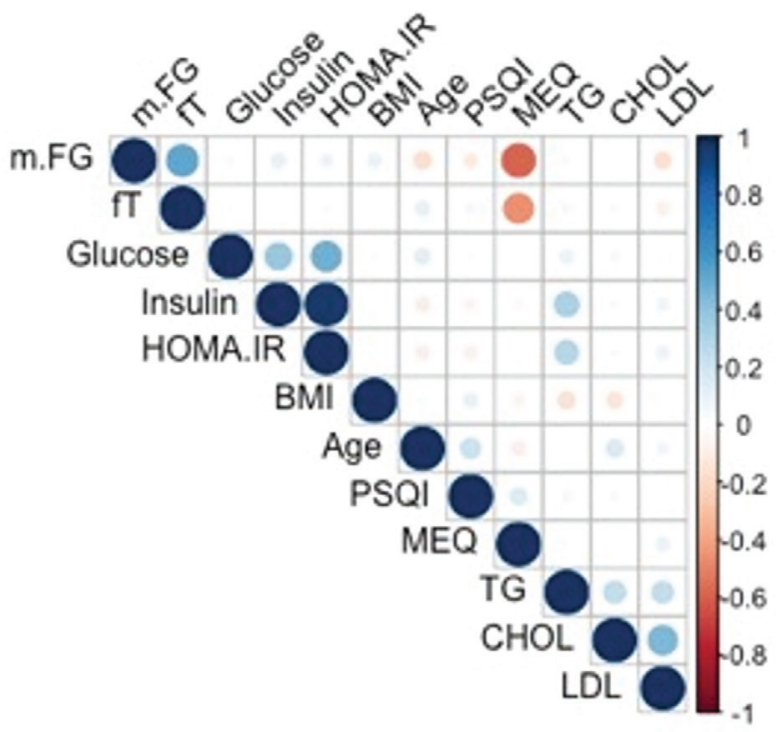

Figure 1. Correlation plot. In this plot higher correlations are represented by larger dots. Blue symbolizes positive correlation and red symbolizes negative correlation. (mFG: modified Ferriman Gallwey Score

fT: Free testesterone, HOMA.IR: Homeostatic Model Assessment for Insulin Resistance index, BMI: Body Mass Index, PSQI: Pittsburgh Sleep Quality index. MEQ: Morningness Eveningness Questionnaire, TG: Triglyceride, CHOL: Total cholesterol, LDL: Low density lipoprotein 
other factors no linear effect on PSQI score was observed. Moreover, MEQ score was inversely correlated with the mFG score: MEQ-mFG $(r=-0.59, p<0.00)$.

For the PCOS group we built a backward stepwise regression model for PSQI and confounding factors. The final regression model with the smallest Akaike's entropybased Information Criterion score (140) includes age, BMI, and MEQ variables. The model indicates that, sleep quality is associated with age $(p=0.002)$ and MEQ $(p=0.001)$.

\section{Discussion}

Our results show that PCOS patients tend to be more evening-type oriented and have worse sleep quality compared to the control group. Within the PCOS group sleep quality was inversely correlated with age. The $\mathrm{mFG}$ score was inversely correlated with the MEQ score.

It has been suggested that evening types are more prone to unhealthy diet, less activity, increased alcohol tobacco consumption; all of which are related to general health disturbances (24). Additionally; eveningness chronotype has been studied in the literature as being associated with unfavorable metabolic outcomes such as higher prevalence of obesity, metabolic syndrome and insulin resistance (25). PCOS patients are prone to increased visceral fat and higher BMI. Considering that the evidence for the treatment of sleep and circadian problems to improve metabolic health is emerging it is of upmost importance to urge our patients to attain healthier lifestyle habits.

Our cohort was constituted of relatively young patients with normal median BMI indexes thus metabolic dysfunction was not as evident as it would have been in an older more diabetic-prone population. The association between PCOS and sleep disturbances is complex and not just due to the tendency of women with PCOS to be obese. Most associations are still evident after adjustment for BMI.

Sleep disturbances in patients with PCOS have been reported before $(26,27)$. Sleep acts as an important modulator of several aspects of endocrine function, making the relationship between these factors difficult to elucidate (28). In the study conducted by Vgontzas and colleaugues; PCOS patients frequently reported more daytime sleepiness than did controls ( $80.4 \%$ vs. $27.0 \%)$ (29). In another study Moran et al. (30) have concluded that sleep disturbances were twice as common in women with PCOS compared to a retrospectively established control group and that PCOS was associated with a higher probability of difficulty falling asleep.

Interestingly, in our present study; we found that participants with hirsutism had more difficulty falling asleep (longer sleep latency-P2 score) compared to PCOS patients without hirsutism. Few studies have investigated the potential role of hyperandrogenemia in sleep disturbance in women. Sleep apnea is more commonly encountered in men; whose testesterone levels are higher than women. Testosterone is associated with upper airway collapsibility in patients with sleep apnea (31). Increased androgen levels in adolescent girls are often associated with obstructive sleep apnea (32). Testosterone levels in female patients with PCOS are known to be generally elevated. The underlying mechanism of this phenomonon is the excess testosterone production in the ovary in response to $\mathrm{LH}$ (33). Elevated androgen levels may affect body composition, visceral fat tissue, airway anatomy, and ventilatory flow during sleep (34). These findings have led us to the belief that testosterone abnormalities may play a role in the pathogenesis of sleep disorders in PCOS patients especially in those who show clinical signs of hyperandrogenism.

The strength of our study is; as far as we are aware it is the first record to find an association with PCOS patients with eveningness chronotype. The limitations of our study was that we analysed biological chronotypes and sleep disturbances based on data derived from selfreported questionnaires. Measuring sleep profiles more accurately by using clinical polysomnography, which is a gold standard test might have contributed to the reliability of our results,

\section{Conclusion}

PCOS patients are more prone to eveningnesschronotype and have worse sleep quality compared to controls. Furthermore PCOS patients with evident clinical hyperandrogenism are more evening oriented and have more difficulty falling asleep compared to those without overt hyperandrogenism. Testosterone abnormalities may play a role in the pathogenesis of sleep disorders in PCOS patients especially in those who show clinical signs of hyperandrogenism.

\section{Authorship Contributions}

Concept: A.F.G.K., Ç.D.Ş., Design: A.F.G.K., Ç.D.Ş., Data Collection or Processing: A.F.G.K., T.T., H.Ç., B.T., Analysis or Interpretation: A.F.G.K., Literature Search: A.F.G.K., T.T., Writing: A.F.G.K.

Financial Disclosure: The authors received no financial support for the research and/or authorship this article.

\section{References}

1. Carmina E, Azziz R. Diagnosis, phenotype, and prevalence of polycystic ovary syndrome. Fertil Steril 2006;86:7-8.

2. Rotterdam ESHRE/ASRM-Sponsored PCOS Consensus Workshop Group. Revised 2003 consensus on diagnostic criteria and long-term health risks related to polycystic ovary syndrome. Fertil Steril 2004;81:19-25. 
3. Hart R, Doherty DA. The potential implications of a PCOS diagnosis on a woman's long-term health using data linkage. J Clin Endocrinol Metab 2015;100:911-9.

4. Twig G, Yaniv G, Levine $H$, et al. Body-Mass Index in 2.3 Million Adolescents and Cardiovascular Death in Adulthood. N Engl J Med 2016;374:2430-40.

5. Golombek DA, Rosenstein RE. Physiology of circadian entrainment. Physiol Rev 2010;90:1063-102.

6. Adan A, Archer SN, Hidalgo MP, Di Milia L, Natale V, Randler C. Circadian typology: a comprehensive review. Chronobiol Int 2012;29:1153-75.

7. Sahbaz C, Devetzioglou T, Ozcelik AM, Kırpınar I. Circadian preferences are associated with vegetative symptoms and comorbid medical diseases in patients with major depression. Biol Rhythm Res 2019;50:703-17.

8. Díaz-Morales JF. Morning and evening-types: exploring their personality styles. Pers Individ Dif. 2007:43:769-78.

9. Takmaz T, Unal B, Ozcan P, et al. Are chronotype and subjective sleep quality associated with preeclampsia and preterm birth?, Biological Rhythm Research.2020;1-13.

10. Steptoe A, O'Donnell K, Marmot M, Wardle J. Positive affect, psychological well-being, and good sleep. J Psychosom Res 2008;64:409-15.

11. Jennings JR, Muldoon MF, Hall M, Buysse DJ, Manuck SB. Self-reported sleep quality is associated with the metabolic syndrome. Sleep 2007;30:219-23.

12. Okubo N, Matsuzaka M, Takahashi I, et al. Relationship between self-reported sleep quality and metabolic syndrome in general population. BMC Public Health 2014;14:562.

13. Laposky AD, Bass J, Kohsaka A, Turek FW. Sleep and circadian rhythms: key components in the regulation of energy metabolism. FEBS Lett 2008;582:142-51.

14. Tuomilehto $H$, Peltonen $M$, Partinen $M$, et al. Sleep duration, lifestyle intervention, and incidence of type 2 diabetes in impaired glucose tolerance: The Finnish Diabetes Prevention Study. Diabetes Care 2009;32:1965-71.

15. Ehrmann DA. Metabolic dysfunction in pcos: Relationship to obstructive sleep apnea. Steroids 2012;77:290-4.

16. Fogel RB, Malhotra A, Pillar G, Pittman SD, Dunaif A, White DP. Increased prevalence of obstructive sleep apnea syndrome in obese women with polycystic ovary syndrome. J Clin Endocrinol Metab 2001;86:1175-80.

17. Subramanian S, Desai A, Joshipura M, Surani S. Practice patterns of screening for sleep apnea in physicians treating PCOS patients. Sleep Breath 2007; 12:233-7.

18. Balen AH, Laven JS, Tan SL, Dewailly D. Ultrasound assessment of the polycystic ovary: international consensus definitions. Hum Reprod Update 2003;9:505-14.

19. Nicandri KF, Hoeger K. Diagnosis and treatment of polycystic ovarian syndrome in adolescents. Curr Opin Endocrinol Diabetes Obes 2012;19:497-504.

20. FERRIMAN D, GALLWEY JD. Clinical assessment of body hair growth in women. J Clin Endocrinol Metab 1961;21:1440-7.
21. Agargun MY, Cilli AS, Boysan $M$, et al. Turkish version of morningness-eveningness questionnaire (MEQ). Sleep Hypn. 2007:9:16

22. Ağargün MY, Kara $H$, Anlar Ö. The validity and reliability of the Pittsburgh Sleep Quality Index. Turk Psikiyatri Derg. 1996:7:107-115.

23. Horne JA, Ostberg O. A self-assessment questionnaire to determine morningness-eveningness in human circadian rhythms. Int J Chronobiol 1976;4:97-110.

24. Partonen T. Chronotype and health outcomes. Curr Sleep Med 2015;1:205-11.

25. Yu JH, Yun $\mathrm{CH}$, Ahn JH, et al. Evening chronotype is associated with metabolic disorders and body composition in middleaged adults. J Clin Endocrinol Metab 2015;100:1494-502.

26. Fernandez RC, Moore VM, Van Ryswyk EM, et al. Sleep disturbances in women with polycystic ovary syndrome: prevalence, pathophysiology, impact and management strategies. Nat Sci Sleep 2018;10:45-64.

27. Tasali E, Van Cauter E, Ehrmann DA. Relationships between sleep disordered breathing and glucose metabolism in polycystic ovary syndrome. J Clin Endocrinol Metab 2006;91:36-42.

28. Andersen ML, Alvarenga TF, Mazaro-Costa R, Hachul HC, Tufik $S$. The association of testosterone, sleep, and sexual function in men and women. Brain Res 2011;1416:80-104.

29. Vgontzas AN, Legro RS, Bixler EO, Grayev A, Kales A, Chrousos GP. Polycystic ovary syndrome is associated with obstructive sleep apnea and daytime sleepiness: role of insulin resistance. J Clin Endocrinol Metab 2001;86:517-20.

30. Moran LJ, March WA, Whitrow MJ, Giles LC, Davies MJ, Moore VM. Sleep disturbances in a community-based sample of women with polycystic ovary syndrome. Hum Reprod 2015;30:466-72.

31. Cistulli PA, Grunstein RR, Sullivan CE. Effect of testosterone administration on upper airway collapsibility during sleep. Am J Respir Crit Care Med 1994;149:530-2.

32. de Sousa G, Schlüter B, Menke T, Trowitzsch E, Andler W, Reinehr T. Relationships between polysomnographic variables, parameters of glucose metabolism, and serum androgens in obese adolescents with polycystic ovarian syndrome. J Sleep Res 2011;20:472-8.

33. Nelson VL, Qin KN, Rosenfield RL, et al. The biochemical basis for increased testosterone production in theca cells propagated from patients with polycystic ovary syndrome. J Clin Endocrinol Metab 2001;86:5925-33.

34. Nandalike K, Agarwal C, Strauss T, et al. Sleep and cardiometabolic function in obese adolescent girls with polycystic ovary syndrome. Sleep Med 2012;13:1307-12. 